\title{
The birth rate in BRICS countries under the gender inequality in the labor market*
}

\author{
K. Kizilova ${ }^{1}$, E.A. Mosakova ${ }^{2}$ \\ ${ }^{1}$ Institute for Comparative Survey Research "Eurasia Barometer" \\ Paniglgasse 17/7, Vienna, 1040, Austria \\ ${ }^{2}$ Lomonosov Moscow State University \\ Leninskye Gory, 1, bldg. 13a, Moscow, Russia, 119991 \\ (e-mail: ksenniya.kizilova@gmail.com; lizavetam@mail.ru)
}

\begin{abstract}
Demographic security under the uneven replacement of population due to significant fluctuations in birthrates is one of the most important problems for many states and global communities. According to the numerous studies, the developed countries face the challenge of depopulation and need to increase fertility, while the developing countries experience demographic boom and need to reduce fertility. The article considers the dynamics of fertility rates in the BRICS countries in the context of gender inequality in labor relations. The authors show that gender discrimination in labor relations affects fertility. The BRICS countries demonstrate that the lower birthrate the higher the level of women's employment, of women's wages, of gender equality in the economic sphere, and the larger the share of female students in the higher education. For the contemporary Russian society this correlation is reverse. The BRICS group consists mainly of developing countries, whose demographic transition has not yet been completed. For this reason, these countries demonstrate a negative correlation between fertility and gender inequality in the labor market. According to the sociological research findings, women there are still challenged with the choice between family and employment. Significant gender inequality in the labor market is an additional factor that forces women into the sphere of family employment. Gender discrimination in the labor market in Russia has a completely different impact on the birthrate than in other BRICS countries: a lower level of gender inequality in the labor market, on the contrary, contributes to the higher fertility. On the one hand, the higher level of gender equality in the labor market makes it easier for women to combine family employment and career, which results in larger number of children per family. On the other hand, the tradition to have several children declines. Therefore, the gender equality policy in a long run determines a smaller number of children per family in the future.
\end{abstract}

Key words: women; employment; fertility; labor market; gender discrimination; BRICS; sociological research

The study of the correlation between employment and the number of children in the family fell into the focus of field-specific literature for the first time only in the middle of the $20^{\text {th }}$ century [11]. It was not until the last quarter of the $20^{\text {th }}$ century that R. Andorka and S. Lloyd proved in their studies of the European countries that women's involvement in economy determines the number of children in the family $[4 ; 10]$. For instance, women found it difficult to combine professional and family duties,

* (C) Kizilova K., Mosakova E.A., 2019.

The article was submitted on 06.03.2019. The article was accepted on 23.04.2019. 
which made them choose between career and family. If the woman chose family with several children, then she had either to leave the labor market or to accept more flexible forms of employment. Thus, the fertility studies in the European countries until the last quarter of the $20^{\text {th }}$ century proved an inverse correlation between fertility and employment.

However, studies in the developed countries in the late $20^{\text {th }}$ - early $21^{\text {th }}$ centuries identified a positive correlation between fertility and women's employment $[1 ; 2 ; 5 ; 8$; $9 ; 12 ; 13]$. Thus, working women demonstrated higher fertility rates than those not employed (the 'fertility rate' stands for 'birthrate', i.e. the number of children per woman; this indicator eliminates the influence of the population age-gender structure). Demographers and sociologists explain this radical change by the demographic transition the correlation between fertility and women's employment changes to the opposite after the transition is completed. Absence of correlation between women's unemployment and fertility is an indirect proof of the positive impact of women's employment on fertility. Thus, the transition of women into unemployment does not lead to a higher birthrate, according to G. Andersson, G. Liu and B. Hoem [3; 6].

There is no unified position on the direction of impact of women's economic employment on fertility. However, numerous researchers and sociologists believe that the most developed countries demonstrated a negative correlation of these indicators before their demographic transition started, and a positive one after its completion [1-3; 5-9; 12; 13].

Multiplicity of the correlation is a consequence of diversely directed impact of a set of factors. The labor market is characterized by the least level of homogeneity of impact including gender discrimination. The problem of gender inequality in the economic sphere exists in all countries despite anti-discriminatory policies of many governments. The Sustainable Development Goals agenda for 2016-2030 testifies to gender discrimination in the economic sphere: one of the goals is "gender equality and empowerment of women and girls" [15].

There has been very little research on the impact of gender discrimination in labor relations on the birthrate. Our aim is to identify whether there is a correlation between birthrate and gender discrimination in the labor market. If such a correlation exists, then what is its direction - is it positive or negative? We considered Russian and international surveys on fertility and women's reproductive behavior, and also official statistics on population and the labor market focusing on the Global Gender Gap-2017 review of the World Economic Forum [15] and on the BRICS countries including Russia. The Gender Inequality Index (GII, reflects the gender gap in politics, economy, education and healthcare) is used as an indicator of the level of gender discrimination in the labor market for it measures difference in sub-indices rather than absolute values. The Total Fertility Rate (TFR) and the Crude Birthrate (CBR) are used as birthrate indicators.

The 2017 research of the BRICS countries helped us to identify several important correlations. First, the higher level of women's involvement in the economic sphere corresponds with the lower birthrate (Table 1) (SAR is an exception as it is traditionally characterized by a higher fertility). 
Table 1

Women's involvement in the economic sphere, $2017[14 ; 16]$

\begin{tabular}{|l|c|c|c|}
\hline \multicolumn{1}{|c|}{ Country } & Level of involvement & GBC, \%o & $\begin{array}{c}\text { TFR } \\
\text { (children per woman) }\end{array}$ \\
\hline India & 0.347 & 19 & 2.43 \\
\hline Brazil & 0.745 & 14.1 & 1.75 \\
\hline SAR & 0.804 & 20.2 & 2.29 \\
\hline China & 0.834 & 12.3 & 1.6 \\
\hline Russia & 0.865 & 11 & 1.61 \\
\hline
\end{tabular}

Table 2

Women's wages in percentage to men's wages for similar jobs and fertility, 2017 [14; 16]

\begin{tabular}{|l|c|c|c|}
\hline \multicolumn{1}{|c|}{ Country } & $\begin{array}{c}\text { Women's wages } \\
\text { in \% to men's }\end{array}$ & CBR, \%o & $\begin{array}{c}\text { TFR } \\
\text { (children per woman }\end{array}$ \\
\hline SAR & 0.547 & 20.2 & 2.29 \\
\hline India & 0.620 & 19 & 2.43 \\
\hline Brazil & 0.517 & 14.1 & 1.75 \\
\hline China & 0.643 & 12.3 & 1.6 \\
\hline Russia & 0.648 & 11 & 1.61 \\
\hline
\end{tabular}

Table 3

GII in the economic sphere, level of women's involvement and fertility, 2017 [14; 16]

\begin{tabular}{|l|c|c|c|}
\hline \multicolumn{1}{|c|}{ Country } & Gll & CBR, \%o & $\begin{array}{c}\text { TFR } \\
\text { (children per woman) }\end{array}$ \\
\hline India & 0.376 & 19 & 2.43 \\
\hline SAR & 0.652 & 20.2 & 2.29 \\
\hline China & 0.654 & 12.3 & 1.6 \\
\hline Brazil & 0.655 & 14.1 & 1.75 \\
\hline Russia & 0.724 & 11 & 1.61 \\
\hline
\end{tabular}

Second, there is a negative correlation between the birthrate and women's wages. This correlation for the BRICS countries can be identified only within homogeneous groups of countries fertility-wise (Table 2). Thus, in the BRICS countries, where birthrate is below the level of demographic replacement (Brazil, Russia, China), there is a negative correlation between the birthrate and gender equality in wages: greater gender equality and same or close wage rates (for similar jobs) are associated with lower birthrates. Similar conclusions can be made for the BRICS countries, where the birthrate level is higher than replacement of the population, in particular in India and Brazil.

Third, there is a negative correlation between birthrate and gender equality in the economic sphere though less notable: the BRICS country demonstrate a higher level of gender equality in the economic sphere with a lower birthrate (Table 3).

Fourth, women's engagement in paid employment is also affected by the level of education, which has a negative impact on fertility. The BRICS countries feature a higher percentage of female students in higher education and a lower birthrate (Table 4).

Fifth, there is a correlation between the levels of Internet usage and fertility. Continuous access to the Internet is usually determined by educational or professional needs, which indirectly presumes higher career aspirations and a higher educational level (Table 5). Thus, lower birthrate corresponds to a higher share of women using the Internet, and the BRICS countries illustrate this trend. 
Kizilova K., Mosakova E.A. RUDN Journal of Sociology, 2019, 19 (4), 630—638

Percentage of women pursuing higher education and fertility, 2017 [14; 16]

Table 4

\begin{tabular}{|l|c|c|c|}
\hline \multicolumn{1}{|c|}{ Country } & $\begin{array}{c}\text { Share of women pursuing higher } \\
\text { education (among women), \% }\end{array}$ & CBR, \%o & $\begin{array}{c}\text { TFR } \\
\text { (children per woman) }\end{array}$ \\
\hline SAR & 23.3 & 20.2 & 2.29 \\
\hline India & 26.7 & 19 & 2.43 \\
\hline China & 47.3 & 12.3 & 1.6 \\
\hline Brazil & 59.3 & 14 & 1.75 \\
\hline Russia & 88.3 & 11 & 1.61 \\
\hline
\end{tabular}

Table 5

Percentage of women using the Internet and fertility, 2017 [14; 16]

\begin{tabular}{|l|c|c|c|}
\hline \multicolumn{1}{|c|}{ Country } & $\begin{array}{c}\text { Percentage of women } \\
\text { using the Internet, \% }\end{array}$ & CBR, \%o & $\begin{array}{c}\text { TFR } \\
\text { (children per woman) }\end{array}$ \\
\hline SAR & - & 20.2 & 2.29 \\
\hline India & - & 19 & 2.43 \\
\hline China & - & 12.3 & 1.6 \\
\hline Brazil & 54.2 & 14 & 1.75 \\
\hline Russia & 73 & 11 & 1.61 \\
\hline
\end{tabular}

Women's engagement in economy and total fertility rate, 1995-2016, Russia

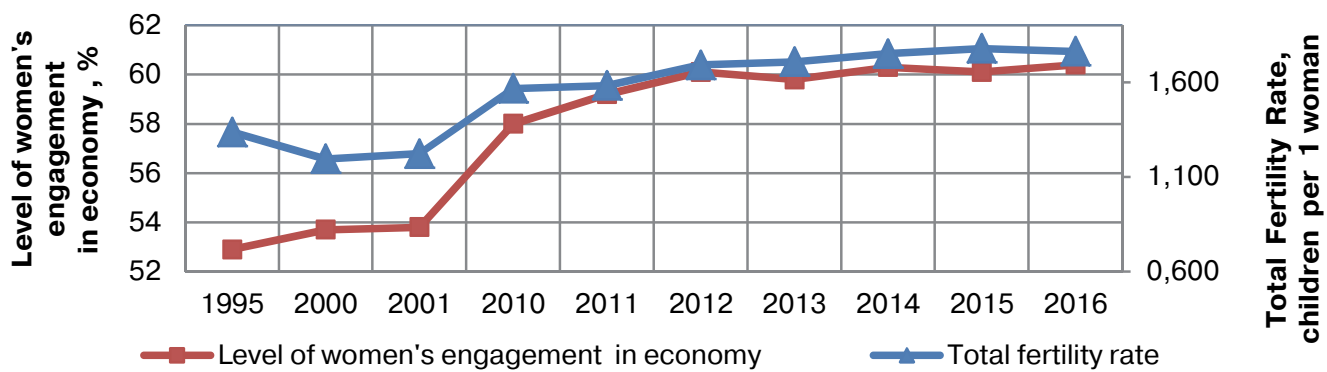

Figure 1. Women's engagement in the economy and fertility (TFR) $[22 ; 23 ; 24 ; 26]$

Thus, the lower is the birthrate (1) the higher is the level of engagement of women in the country's economic sphere; (2) the more equal are wage rates for women and men; (3) the higher is the level of gender equality in the economic sphere; (4) the higher is the share of female students in higher education and of women using the Internet. However, the BRICS countries present a diversity of demographic parameters, not every country has completed its demographic transition. Let us focus on the identified correlations for Russia.

First, the birthrate and employment of women in Russia were changing in diverging directions until the early 2000s, which illustrated a negative correlation between the indicators (Fig. 1). However, Russia completed its demographic transition by the end of the $20^{\text {th }}$ century, which determined a considerable reduction of the birthrate the child generation no longer replenishes the parent generation. A new trend has developed since the 2000 s - a positive correlation between the women's economic engagement and fertility. There has been either simultaneous growth or simultaneous decline of both indicators; and participation in the paid employment has had a positive impact on fertility. Thus, the participation of women in labor relations is the factor that contributes to the higher birthrate, unlike other BRICS countries. 
Correlation between women's wages to that of men and fertility, Russia [25; 26]

\begin{tabular}{|c|c|c|}
\hline Year & $\begin{array}{c}\text { Correlation between women's } \\
\text { and men's wages, \% }\end{array}$ & $\begin{array}{c}\text { TFR } \\
\text { (children per woman) }\end{array}$ \\
\hline 2005 & 60.7 & 1.294 \\
\hline 2007 & 63.1 & 1.416 \\
\hline 2009 & 65.3 & 1.542 \\
\hline 2011 & 64.1 & 1.582 \\
\hline 2013 & 74.2 & 1.707 \\
\hline 2015 & 72.6 & 1.777 \\
\hline 2017 & 71.7 & 1.621 \\
\hline
\end{tabular}

The educational level of the population and fertility, Russia $[19 ; 20 ; 21 ; 26]$

\begin{tabular}{|c|c|c|}
\hline Year & $\begin{array}{c}\text { People with higher education } \\
\text { (per 1000 persons of relevant birth cohort) }\end{array}$ & $\begin{array}{c}\text { TFR } \\
\text { (children per woman) }\end{array}$ \\
\hline 1989 & 109 & 1.892 \\
\hline 2002 & 165 & 1.286 \\
\hline 2010 & 248 & 1.567 \\
\hline 2015 & 339 & 1.77 \\
\hline
\end{tabular}

Second, in the past decade Russia, unlike other BRICS countries, presents a direct correlation between the birthrate and gender gap in wages: the closer the level of women's wages to those of men, the higher the birthrate (Table 6).

Third, the comparison between the educational levels of women and fertility in recent decades allows to identify a direct correlation between the indicators, unlike other BRICS countries. For instance, women in Russia strive for equal rights with men, which leads to a certain level of education as well as professional selfrealization, which competes with the need to have several children. Consequently, the number of children drops. The analysis of the census data of 1989, 2002, 2010, and micro-census of 2015 seems to be most informative for they provide information on the educational level of the population (Table 7). Until the 2000s, Russia saw an inverse correlation between the birthrate and higher education among women: the share of women with higher education was surging, the birthrate was declining. However, we saw a simultaneous growth of both indicators since the $2000 \mathrm{~s}$, which means their positive correlation. The comparison of the micro-census data (2015) and results of the latest census (2002) is very illustrative: the share of women with higher education doubled, while increased by $30 \%$.

Thus, in recent decades in Russia, the higher birthrate was associated with (1) the higher level of women's engagement in the economy; (2) the greater equality in wages; (3) the higher gender equality in the economic sphere; and (4) the higher share of women with higher education.

According to many sociological studies, women still face the choice between family and professional duties in the BRICS countries. When making decision about carrier, women who refuse paid employment for family employment tend to have a greater number of children. When making a choice in favor of the family and several children, women usually have to leave the sphere of paid employment, which, in turn, results in the lower fertility rates and fewer children in the family. The gender inequality 
in the labor market of the BRICS countries works as an additional factor that pushes women into family employment, thus, making their choice even more difficult. For this reason, the higher gender equality in the labor market of the BRICS countries as well as an increase in women's employment are accompanied by shrinking fertility.

Wage rates and education are two factors that are closely linked with women's involvement in the labor market. The comparative analysis of the BRICS countries in 2017 shows that there was an inverse correlation between the birthrate, on the one hand, and the level of education and gender gap in wages, on the other. The more a woman is discriminated in the labor market, in particular, concerning her payment, the lower her wages and the more reasonable for her to leave the labor market and to devote herself to the family. The same is proven by the inverse correlation of the birthrate and the level of education in the BRICS countries: the higher educational level of women affects their values and priorities; the higher level of education contributes to the greater emphasis women place on professional development and, consequently, the family becomes of smaller importance, and vice versa.

The inverse correlation between the women's involvement in the labor market and the birthrate is explained by the fact that the BRICS consists primarily of developing counties. Russia and China - transitional economies - are the only exceptions, according to the IMF. For some developing countries the demographic transition is yet not completed, and these societies demonstrate an inverse correlation of the birthrate and the mentioned above factors. Thus, the gender discrimination in Russia has a different impact on the birthrate as compared to other BRICS countries. Russia has experienced either parallel growth or decline of the birthrate and the level of employment in recent decades: women's engagement in labor relations today is the factor contributing to the higher birthrate $[16 ; 18]$. This can be stipulated by both the completed the demographic transition in the late $20^{\text {th }}$ century and the traditionally higher level of employment of women. The development of labor relations in the USSR (and Russia as its successor state) was aimed at maximization of women involvement in the economic sphere for the increase in production and improvement of economic performance of the state during the post-war recovery of the country. We should note that in 1990-2017 the share of women in the gender structure of the labor market did not change substantially (it went up by 1\%) [24-26]. Thus, the Russian labor market offers nearly equal opportunities to both gender groups, and women find it much easier to combine family life and professional employment as compared to other BRICS countries.

However, the reasons why Russian women choose the paid employment differ considerably from other countries and Western Europe in particular. For many women this choice is largely motivated by the need to support their family: the income of one wage-earner usually is not enough to provide for the whole family even with one child, which pushes women into the labor market. The gender gap in wages is another factor contributing to women's employment. Russia saw a narrowing gender gap in wages in the last decade, which was largely determined by the reduction of the active workingage population: the small generation born during the deep economic crisis in the 1990s was becoming a workforce, while the larger generation born in the 1960s was retiring. This led to a workforce deficit, and employers had to cover it by higher wages for women, which are now close to men's wages. This explains to a great extent the direct correla- 
tion between the gender gap in wages and fertility: the closer the levels of payment to men and women, the higher the birthrate.

The correlation between the birthrate and the level of education in Russia also differs substantially from other BRICS countries: a larger share of women with higher education has more children. The educational level and the level of employment are the factors contributing to fertility. The causes that led to the change in the correlation between the educational level and birthrate are comparable with those that affected the level of women's employment. The correlation between the educational level and fertility (TFR) was negative before demographic transition and is positive after its completion.

Gender discrimination in the labor market that includes a range of interrelated factors, is one of the crucial determinants of fertility. The country's social and economic development and peculiarities of its demography, in particular the completion of the demographic transition, determine these correlations. For instance, factors associated with women's employment, such as the gender gap in economy, women's wages as compared with those for men, and higher education level of women have a negative impact on the birthrate in BRICS, which consists mainly of developing countries, while in Russia, which is a country with transitional economy, according to the IMF methodology, the impact is positive. This represents a paradox of the contemporary labor market: on the one hand, a greater gender equality makes it easier for women to combine family employment and career resulting in more children in the family. On the other hand, the same contributes to the decline in the possibility to have several children, which becomes specifically relevant for future generations of women. Thus, the number of children per family declines despite the gender equality policy.

\section{References}

[1] Ahn N., Mira P. A note on changing relationship between fertility and female employment rates in developed countries. Journal of Population Economics. 2002; 15.

[2] Anderson G., Scott K. Childbearing dynamics of couples in a universalistic welfare state: The role of labor-market status, country of origin, and gender. Demographic Research. 2007; 17.

[3] Andersson G., Liu G. Demographic trends in Sweden: Childbearing developments in 19612000, marriage and divorce developments in 1971-1999. Demographic Research. 2001; 5.

[4] Andorka R. Determinants of Fertility and Advanced Societies. New York: Free Press; 1978.

[5] Heer D. Society and Population. Englewood Cliffs: Prentice-Hall; 1968.

[5] Hoem B. Entry into motherhood in Sweden: The influence of economic factors on the rise and fall in fertility 1986-1997. Demographic Research. 2000; 2.

[6] Hoem B. The compatibility of employment and childbearing in contemporary Sweden. Acta Sociologica. 1993; 36.

[7] Kharkova T.L., Andreev E.M. Did the economic crisis cause the fertility decline in Russia? Evidence from the 1995 micro-census. European Journal of Population. 2000; 16.

[8] Kohler H.P., Kohler I. Fertility decline in Russia in the early and mid-1990s: The role of economic uncertainty and labor market crisis. European Journal of Population. 2001; 18.

[9] Lloyd C. The contribution of the world fertility surveys to an understanding of the relationship between women's work and fertility. Studies in Family Planning. 1991; 22 (3).

[10] Myrdal A., Klein Y. Women's Two Roles: Home and Work. London: Routledge; 1956.

[11] Sweet J.A. Woman in the Labor Force. New York: Seminar Press; 1973. 
[12] Tevenon O. Family policies in developed countries: Contrasting models. Population \& Societies. $2008 ; 448$.

[13] The World Factbook: TFR by countries of the world. 2017. https://www.cia.gov/library/ publications/resources/the-world-factbook/geos/ch.html.

[14] Transforming Our World: The 2030 Agenda for Sustainable Development. United Nations; 2015.

[15] World Economic Forum: The Global Competitiveness Report. 2017. http://www3.weforum.org/ docs/WEF_GGGR 2017.pdf.

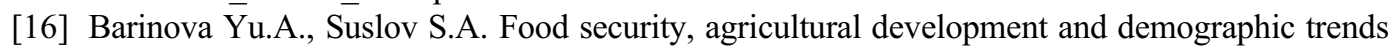
in some RF territories. NGIEI Bulletin. 2013; 1 (In Russ.).

[17] Bunkovsky D.V. Shadow economy: A development analysis. Bulletin of the East-Siberian Institute of the Russian Ministry of Interior. 2015; 4 (In Russ.).

[18] Women and Men in Russia. 2006: Statistical Digest. Moscow; 2007 (In Russ.).

[19] Women and Men in Russia. 2016: Statistical Digest. Moscow; 2016 (In Russ.).

[20] Education by Numbers: 2017: A Brief Statistic Digest. Moscow; 2017 (In Russ.).

[21] Work and Employment in Russia: 2003: Statistical Digest. Moscow; 2003 (In Russ.).

[22] Work and Employment in Russia: 2015: Statistical Digest. Moscow; 2015 (In Russ.).

[23] Work and Employment in Russia: 2017: Statistical Digest. Moscow; 2017 (In Russ.).

[24] State Statistics Federal Service of the Russian Federation: Relationship between Women's and Men's Wages. http://www.gks.ru/wps/wcm/connect/rosstat_main/rosstat/ru/statistics/wages/ labour_costs/\# (In Russ.).

[25] State Statistics Federal Service of the Russian Federation: TFR in Russia. http://www.gks.ru/ $\mathrm{wps} / \mathrm{wcm} / \mathrm{connect} /$ rosstat_main/rosstat/ru/statistics/population/demography/\# (In Russ.).

DOI: 10.22363/2313-2272-2019-19-4-630-638

\title{
Уровень рождаемости в странах БРИКС в контексте гендерного неравенства на рынке труда*
}

\author{
К. Кизилова ${ }^{1}$, Е.А. Мосакова ${ }^{2}$ \\ ${ }^{1}$ Институт сравнительных исследований общественного мнения \\ «Евразийский барометр» \\ Панингассе 17/7, Вена, 1040, Австрия \\ ${ }^{2}$ Московский государственный университет им. М.В. Ломоносова \\ Ленинские горы, 1, стр. 13а, Москва, Россия 119991
}

\begin{abstract}
В условиях неравномерного воспроизводства населения вследствие значительных скачков в уровне рождаемости демографическая безопасность становится важнейшей проблемой для многих государств и глобальных сообществ. Согласно данным многочисленных исследований развитые страны сталкиваются с проблемой депопуляции и нуждаются в повышении уровня рождаемости, тогда как развивающиеся страны, напротив, переживают демографический бум и стремятся снизить уровень рождаемости. Авторы рассматривают динамику показателей рождаемости в странах БРИКС в контексте гендерного неравенства в сфере трудовых отношений и показывают, как это неравенство влияет на уровень рождаемости. Для стран БРИКС характерна следующая ситуация: чем ниже уровень рождаемости, тем выше уровень занятости, заработная плата женщин, гендерное равенство в экономической сфере и доля женщин, получающих высшее образование. В современной России
\end{abstract}

* (с) Кизилова К., Мосакова Е.А., 2019.

Статья поступила 06.03.2019 г. Статья принята к публикаџии 23.04.2019 2. 
наблюдается обратная ситуация, поскольку БРИКС состоит преимущественно из развивающихся стран, где демографический переход пока еще не завершен, и потому эти страны демонстрируют обратное соотношение рождаемости и гендерного неравенства на рынке труда. Согласно социологическим данным женщины здесь все еще сталкиваются с проблемой выбора между семьей и работой. Высокий уровень гендерного неравенства на рынке труда — дополнительный фактор, который выталкивает женщину в сферу семейной занятости. Гендерная дискриминация на российском рынке труда оказывает иное воздействие на уровень рождаемости, чем в других странах БРИКС: низкий уровень гендерного неравенства на рынке труда, напротив, обеспечивает более высокую рождаемость. С одной стороны, более высокий уровень гендерного равенства на рынке труда облегчает женщинам совмещение семейных обязанностей и карьеры, что приводит к большему количеству рождений детей на семью. С другой стороны, уходит традиция рождения нескольких детей. Соответственно, в долгосрочной перспективе политика гендерного равенства приведет к сокращению количества детей на семью в будущем.

Ключевые слова: женщины; занятость; рождаемость; рынок труда; гендерная дискриминация; страны БРИКС; социологическое исследование 